Discussion Paper No. 04-10

\title{
The Impact of Macroeconomic Uncertainty on Cash Holdings for Non-Financial Firms
}

Christopher F. Baum; Mustafa Caglayan, Neslihan Ozkan and Oleksandr Talavera

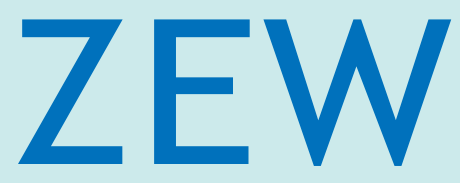

Zentrum für Europäische Wirtschaftsforschung $\mathrm{GmbH}$

Centre for European

Economic Research 
Discussion Paper No. 04-10

\title{
The Impact of Macroeconomic Uncertainty on Cash Holdings for Non-Financial Firms
}

\author{
Christopher F. Baum; Mustafa Caglayan, \\ Neslihan Ozkan and Oleksandr Talavera
}

Download this ZEW Discussion Paper from our ftp server:

ftp://ftp.zew.de/pub/zew-docs/dp/dp0410.pdf

Die Discussion Papers dienen einer möglichst schnellen Verbreitung von neueren Forschungsarbeiten des ZEW. Die Beiträge liegen in alleiniger Verantwortung der Autoren und stellen nicht notwendigerweise die Meinung des ZEW dar.

Discussion Papers are intended to make results of ZEW research promptly available to other economists in order to encourage discussion and suggestions for revisions. The authors are solely responsible for the contents which do not necessarily represent the opinion of the ZEW. 


\section{NON-TECHNICAL SUMMARY}

The concept of the profit-maximizing firm is a cornerstone of economic analysis. A realistic model of firm behavior under uncertainty may assume that the ultimate goal of a firm is to ensure long-term survival. In this framework, firms are expected to hold liquid assets to mitigate future unfavorable movements in the economy. For instance, Kester (1986), studying a sample of 452 US firms in 1983, reports that their average ratio of cash plus marketable securities to total assets is $8.6 \%$; later Kim et al. (1998) report an average of $8.1 \%$ for a sample of 915 US industrial firms over 1975-1994. What determines the optimal amount of liquid assets that a firm should hold?

Recent research carried out by Opler et al. (1999), Ozkan and Ozkan (2003), and Faulkender (2002) has focused on the role of firm-specific characteristics such as leverage, growth opportunities, cash flow, and cash flow uncertainty as the main determinants of corporate cash holdings. These researchers find that firms that are small and non-rated hold more cash than large firms. One can interpret these findings to suggest that firms facing a high degree of asymmetric information are likely to hold more cash because of potential difficulties in their access to external financing.

In addition to firm-specific variables, macroeconomic aggregates could be an important determinant of firms' cash-holding behavior, and one that has received little attention in previous research. Our methodology is based on an analytical prediction: the cross-sectional distribution of non-financial firms' cash-to-asset ratios should be systematically affected by the degree of macroeconomic uncertainty. Under this hypothesis, the second moments matter: for any given trajectory of monetary policy, firms will behave more homogeneously, and the cross-sectional distribution of cash/asset ratios will narrow in the presence of heightened macroeconomic uncertainty.

We utilise a cash buffer-stock model augmented with a signal extraction framework, where a non-financial firm's manager adjusts her cash holdings to minimize the expected costs of cash management. The model implies that the manager will alter her cash holdings in anticipation of variations in macroeconomic shocks. The Standard and Poor's COMPUSTAT Industrial Annual database of U.S. non-financial firms is used for testing our hypothesis. It covers on average 3,600 firms' annual characteristics from 1957 to 2000.

According to our empirical estimations we find that non-financial firms become more homogeneous in their behavior in response to an increase in macroeconomic uncertainty, behaving more conservatively with respect to their cash holdings in more uncertain times. Large firms, durable-goods makers, highgrowth firms and firms facing financial constraints make larger adjustments in their cash holdings in response to macroeconomic volatility. These results are shown to be robust to the inclusion of the levels of macroeconomic factors such as the index of leading indicators and the rate of inflation. 


\title{
The Impact of Macroeconomic Uncertainty on Cash Holdings for Non-Financial Firms
}

\author{
Christopher F. Baum* \\ Department of Economics \\ Boston College \\ Mustafa Caglayan \\ Department of Economics \\ University of Leicester \\ Neslihan Ozkan \\ Department of Economics \\ University of Bristol \\ Oleksandr Talavera \\ Department of Economics, Boston College \\ Europa-Universität Viadrina
}

January 28, 2004

\footnotetext{
${ }^{*}$ We are grateful to seminar participants at the University of Liverpool, University College Dublin, the University of Tennessee-Knoxville, the University of Connecticut, the Center for European Economic Research (ZEW) and the Ninth International Conference of the Society for Computational Economics for their comments, and to Paula N. Arnold for editorial suggestions. Talavera thanks ZEW for hospitality during the course of this research. The standard disclaimer applies. Corresponding author: Christopher F. Baum, Department of Economics, Boston College, Chestnut Hill, MA 02467 USA, Tel: 617-5523673, fax 617-552-2308, e-mail: baum@bc.edu.
} 
The Impact of Macroeconomic Uncertainty on Cash Holdings for Non-Financial Firms

\begin{abstract}
This paper investigates the effects of macroeconomic volatility on non-financial firms' cash holding behavior. Using an augmented cash buffer-stock model, we demonstrate that an increase in macroeconomic volatility will cause the cross-sectional distribution of firms' cash-to-asset ratios to narrow. We test this prediction on a panel of non-financial firms drawn from the annual COMPUSTAT database covering the period 1957-2000, and find that as macroeconomic uncertainty increases, firms behave more homogeneously. Our results are shown to be robust to the inclusion of the levels of several macroeconomic factors.
\end{abstract}

Keywords: Cash holdings, macroeconomic uncertainty, time series, ARCH, non-financial firms. 


\section{Introduction}

Some recent quotations indicate that non-financial firms maintain very large cash holdings. For example, Apple Computer reported in October, 2002: "For the year, the Company reported net earnings of $\$ 65$ million on revenues of $\$ 5.74$ billion, compared to a net loss of $\$ 25$ million on revenues of $\$ 5.36$ billion in $2001 \ldots$ We were extremely pleased with our ability to achieve our revenue target for the fourth quarter while reducing channel inventory to a normal level... Continued strong asset management enabled us to maintain a solid balance sheet with over $\$ 4.3$ billion in cash..." ${ }^{1}$ How prevalent is this cash-hoarding behavior?

Kester (1986), studying a sample of 452 US firms in 1983, reported that their average ratio of cash plus marketable securities to total assets is $8.6 \%$; later Kim et al. (1998) reported an average of $8.1 \%$ for a sample of 915 US industrial firms over 1975-1994. In our sample of COMPUSTAT firms, the average cash-to-asset ratio for all non-financial firms over the last 48 years is $11.9 \%$ with a significant difference between large and small firms' ratios, $8.7 \%$ versus $14.3 \%$, respectively. Why do firms hold these levels of liquid assets? Over the years, many researchers have asked similar questions and provided various explanations. One potential explanation is that cash provides low-cost finance in a world with financial market imperfections and failures. Therefore, firms would want to hold cash far in excess of their transactions needs to mitigate the effects of unfavorable changes in interest rates or restrictions on their access to credit. In essence, these high levels of liquid assets may be viewed as options purchased by the firms' managers that may be exercised in adverse times (via drawdowns) to ensure the long-term

\footnotetext{
${ }^{1}$ Citation (emphasis added): Fred Anderson, CFO, in Apple Computer Inc. press release, 16 October 2002, http://www.apple.com/pr/library/2002/oct/16earnings.html
} 
survival of the firm as a going concern.

Recent research carried out by Opler et al. (1999), Ozkan and Ozkan (2003), and Faulkender (2002) has focused on the role of firm-specific characteristics such as leverage, growth opportunities, cash flow, and cash flow uncertainty as the main determinants of corporate cash holdings. ${ }^{2}$ They found that small, non-rated firms and firms with strong investment opportunities and riskier cash flows hold more cash. One can interpret these findings to suggest that firms facing a high degree of asymmetric information are likely to hold more cash because of potential difficulties in their access to external financing.

In addition to firm-specific variables, macroeconomic aggregates could be an important determinant of firms' cash-holding behavior and one that has received little attention in previous research. ${ }^{3}$ In this paper, we aim to contribute to the literature on corporate cash holdings by arguing that volatility in macroeconomic conditions would affect managers' determination of the appropriate level of liquid asset holdings. Hence, a firm facing higher uncertainty in its cash flows may find it optimal to accumulate liquid assets, in the form of cash, in order to offset the adverse effects of negative cash flow shocks. Given that all managers will face this choice to a greater or lesser degree, we expect that changes in macroeconomic stability will trigger adjustments in firms' liquid assets holdings as managers react to volatile economic conditions. Naturally, this would in turn generate variations in the cross-sectional distribution of corporate cash holdings.

To explore the effects of macroeconomic uncertainty on firms' cash hold-

\footnotetext{
${ }^{2}$ Other related papers include Almeida et al. (2004) and Dittmar et al. (2003).

${ }^{3}$ One exception is the work of Almeida et al. (2004), which examined firms' cash flow sensitivity of cash holdings over the business cycle. Additionally, views of a broad "credit channel" have considered the sensitivity of firms' net worth and creditworthiness to macroeconomic factors.
} 
ing behavior, we construct a simple cash-buffer model augmented with a signal extraction framework. The model generates a testable hypothesis: one should observe a negative link between macroeconomic uncertainty and variation in the cross sectional distribution of firms' cash-to-asset ratios. Increasing macroeconomic uncertainty will hinder managers' ability to accurately forecast future cash flows, leading them to behave more conservatively. This will cause the dispersion of the cross-sectional cash-to-asset ratio to fall. Conversely, in times of greater macroeconomic stability, managers will be able to produce more accurate forecasts of cash flows, allowing them to have more latitude to behave idiosyncratically, leading to a broadening of the cross-sectional dispersion of firms' cash-to-asset ratios.

Our modeling and empirical strategy differ from the prevalent approach that generally links the level (or the changes) of firms' cash holdings to various firm-specific characteristics in order to explain the cash holding behavior for the representative firm. In contrast, our approach allows one to understand the cash holding behavior of the entire group of firms under scrutiny rather than that of the representative firm. We should point out that although different, these two methodologies are not contradictory; rather, they are complementary analyses. Our strategy also differs from that of much of the literature by allowing us to study the much-debated (but never properly tested) hypothesis that macroeconomic uncertainty affects firms' cash holding behavior. To ascertain the impact of macroeconomic uncertainty on the cross-sectional distribution of firms' cash-to-asset ratios, we utilize a panel of non-financial firms obtained from the COMPUSTAT database over the 1957-2000 period. Our data set contains over 200,000 firm-years, with an average of 3,600 firms per annum. ${ }^{4}$

\footnotetext{
${ }^{4}$ Considering the fact that the COMPUSTAT database covers the strongest and the largest firms in the US economy, generalizing our observations as typical of corporate
} 
We can summarize our results as follows. The data yield a clear negative relationship between the variance of the cross-sectional distribution of non-financial firms' cash-to-asset ratios and a proxy for macroeconomic uncertainty, the conditional variance of real gross domestic product. In our regression analysis, we incorporate several additional variables to gauge the robustness of our findings and guard against potential misspecification of the model. Our analysis provides evidence that the relationship is robust to inclusion of these variables.

The rest of the paper is constructed as follows. Section 2 presents a simple model of the influence of macroeconomic uncertainty on the optimal cash holdings of non-financial firms. Section 3 describes the data and discusses our results. Finally, Section 4 concludes and gives suggestions for further research.

\section{Cash holdings under uncertainty}

Some non-financial corporations hold significant amounts of cash equaling a considerable fraction of their annual turnover. ${ }^{5}$ Why do firms hold a significant fraction of their assets in the form of cash? There has been extensive literature on corporate cash holding, going back to Keynes (1936). He suggests three major motives for cash holdings: (1) the transactions motive, (2) the precautionary motive and (3) the speculative motive. In general, a firm will hold cash to meet its transaction needs that would arise in the course of carrying out its daily business activities. The precautionary motive requires behavior might be considered reasonable.

${ }^{5}$ One may recall a well publicized dispute in 1996 between Robert J. Eason, the Chairman of Chrysler Corporation, and the investor Kirk Kerkorian over the latter's proposal for the distribution of cash and marketable securities in excess of $\$ 7.5$ billion to shareholders in the form of share repurchases and dividends. 
that a firm will accumulate cash to meet its unanticipated contingencies that may arise, while the speculative motive argues that a firm will accumulate cash to take advantage of profit-making opportunities that may develop. ${ }^{6}$

Recent research (see, for example, Ozkan and Ozkan (2003) and references therein) has emphasized the importance of firm-specific characteristics as a determinant of firms' cash-holding behavior. However, the macroeconomic environment within which firms operate could be an equally important determinant. For instance, in March, 2001, Business Week reported: "So with the economy stalling and fears of recession rising, executives are becoming more concerned about protecting the cash they've got. 'People are more conservative than they were a year ago,' says Charles G. Ward III, co-head of investment banking at Credit Suisse First Boston. 'CEOs and CFOs are making sure they have bank lines and cash, and they want to make sure capital expenditures don’t outstrip their cash-raising capability.' Adds Richard H. Brown, CEO of technology-services giant Electronic Data Systems Corp.: 'Cash is king now." 7 This quotation suggests that managers, finding it difficult to accurately forecast their firm's future cash flows in a context of increasing macroeconomic uncertainty, may decide to increase their firms' cash holdings due to precautionary reasons. Such a conservative response on the part of all managers would lead to a reduction in the cross-sectional dispersion of firms' cash-to-asset ratios. Conversely, macroeconomic stability provides managers with the ability to more accurately forecast their firms'

\footnotetext{
${ }^{6}$ One would expect stronger motives for corporate cash holdings to appear in an imperfect financial market, where external finance involves a high premium. Adverse selection and moral hazard problems stemming from information asymmetry between lenders and borrowers would lead to costly external financing. Thus, firms - particularly those with a high degree of informational asymmetry-would tend to accumulate more cash to avoid high costs of external finance.

${ }^{7}$ Citation: Business Week, 12 March 2001. "In Today's Corporate America, Cash Is King." http://www.businessweek.com/magazine/content/01_11/b3723021.htm.
} 
future cash flows and will give them the latitude to behave more idiosyncratically.

Surprisingly, to our knowledge there is no study which explicitly considers the influence of macroeconomic uncertainty on firms' demand for liquidity. However, in a related context, Beaudry et al. (2001) investigated the effects of monetary uncertainty on firms' fixed investment behavior, while Baum et al. (2002) considered the effects of macroeconomic uncertainty on commercial banks' lending activity. In particular, Beaudry et al. presented a simple macro model to illustrate the effects of monetary instability on the crosssectional dispersion of fixed investment. Using a panel of UK manufacturing firms over the period 1970-1990, they showed that an increase in uncertainty, as captured by the variance of the CPI, narrows the distribution of firms' investment rates. In a similar vein, Baum et al. (2002) developed a model to demonstrate existence of a negative relationship between macroeconomic uncertainty and the cross-sectional variance of US banks' loan-to-asset ratios. They provided evidence in favor of their hypothesis using a panel of quarterly bank data derived from the Federal Reserve System's Commercial Bank and Bank Holding Company database over 1979-2000. In both studies, the authors ensured the robustness of their results by incorporating various additional variables to their basic model that can affect the relationship.

In this paper, we argue that a firm facing higher uncertainty in its cash flows may find it optimal to behave more conservatively with respect to its cash holdings for precautionary reasons, as explained above. Given that all managers are faced with a similar problem, adjustments in liquid assets in turn generate predictable variations in the cross-sectional distribution of corporate cash holdings. To provide a basis for our hypothesis and our empirical work, we present a basic cash buffer-stock model augmented with a signal 
extraction framework. For tractability, our model only contains the basic building blocks required to link the dispersion of firms' cash-to-total assets ratio to macroeconomic variability. In our empirical work, similar to Beaudry et al. and Baum et al., we incorporate several additional variables to gauge the robustness of our findings and guard against potential misspecification of the model.

\section{$2.1 \quad$ The model}

A straightforward cash buffer-stock model augmented with a signal extraction framework, where a non-financial firm's manager adjusts her cash holdings to minimize the expected costs of cash management, implies that the manager will alter her cash holdings in anticipation of variations in macroeconomic shocks. ${ }^{8}$ Initially, we assume that the firm's cash flow is uniformly distributed, while the upper and lower bound of the distribution are known to the manager and are identical across all firms. We show that the optimal amount of cash holdings will crucially depend on the bounds of the distribution, as well as the opportunity cost of holding cash and the cost of borrowing. Then, we allow these bounds to be subjected to a random shock. ${ }^{9}$ Augmenting the basic model with a signal extraction framework, we then show that the manager's ability to accurately predict future cash flow is important. Using this aspect of the model, we link the variance of the cross-sectional distribution of firms' cash-to-asset ratios to macroeconomic uncertainty.

\footnotetext{
${ }^{8}$ Models developed by Whalen (1966), Schnure (1998), and Frenkel and Jovanovic (1980) motivate our analytical approach.

${ }^{9}$ This assumption provides that cash holdings across firms are no longer identical.
} 


\subsubsection{The basic cash buffer-stock model}

Assume that in each period, firm $i$ receives an uncertain amount of net cash flow ${ }^{10}$ between time $t$ and $t+1$, drawn from a uniform distribution with an upper bound $H$, and a lower bound, $L=-H$. The manager of the firm, seeking to continue its operations, would want to hold an optimal amount of cash buffer for precautionary reasons, which involves an opportunity cost of $r_{1}$ percent. If there is a negative cash flow shock that exceeds current cash holdings, the firm has to borrow from an external source to meet its obligations at a higher interest rate of $r_{2}$ percent. We assume that $r_{2}>r_{1}$, and possibly $r_{2}>>r_{1}$. Here, a firm holding a cash buffer of $C_{i}$ faces the following three possible outcomes.

First, the net cash flow of the firm could be positive, so that the firm merely faces the opportunity cost of holding $C_{i}{ }^{11}$

$$
\operatorname{COST}_{1}=C_{i} r_{1}
$$

with probability $P_{1}=\frac{H}{2 H}=\frac{1}{2}$.

Second, the firm could face a negative cash shock $\left(C F_{i}\right)$ of a magnitude up to $C_{i}$. The cost now includes the opportunity cost of holding the cash buffer as well as the cost of replenishing it:

$$
C O S T_{2}=C_{i} r_{1}-E\left(C F_{i} \mid-C_{i}<C F_{i}<0\right)=C_{i} r_{1}-\frac{-C_{i}}{2}
$$

which occurs with a probability of $P_{2}=\frac{C_{i}}{2 H}$.

Finally, as the third case, the firm may not have enough cash to cover the negative shock and has to borrow from external sources at a higher interest

\footnotetext{
${ }^{10} \mathrm{We}$ assume that the firm has certain cash outflows, but that inflows are random in their timing (e.g. invoices will be paid, but may be paid in a later accounting period than that in which they are due.)

${ }^{11}$ Any unused cash is assumed to be distributed back to the shareholders in the form of dividends or share repurchases.
} 
rate to remain solvent: ${ }^{12}$

$$
\begin{aligned}
\operatorname{COST}_{3}= & C_{i} r_{1}+C_{i}-\left(E\left(C F_{i} \mid-H<C F_{i}<-C_{i}\right)+C_{i}\right)\left(1+r_{2}\right)= \\
& =C_{i} r_{1}+C_{i}+\left(\frac{H-C_{i}}{2}\right)\left(1+r_{2}\right) .
\end{aligned}
$$

In this case, the firm bears the full opportunity $\operatorname{cost} C_{i} r_{1}$ and must fully replenish its cash buffer to the optimal level $C_{i}$. Furthermore, the firm borrows an additional amount from an external source at the gross interest rate $\left(1+r_{2}\right)$, with a probability of $P_{3}=\frac{H-C_{i}}{2 H}$.

Therefore, given all possible costs associated with holding cash as expressed in equations $1-3$, the manager of the firm would want to minimize its total expected cost, $E C O S T=C O S T_{1} P_{1}+C O S T_{2} P_{2}+C O S T_{3} P_{3}$, which takes the following form after some manipulation:

$$
\begin{aligned}
\operatorname{ECOST}= & \frac{1}{2} C_{i} r_{1}+\left(C_{i} r_{1}-\frac{-C_{i}}{2}\right) \frac{C_{i}}{2 H}+ \\
& \left(C_{i} r_{1}+C_{i}+\left(\frac{H-C_{i}}{2}\right)\left(1+r_{2}\right)\right) \frac{H-C_{i}}{2 H} .
\end{aligned}
$$

The first order conditions imply that the optimal cash buffer will be ${ }^{13}$

$$
C_{i}=\frac{H}{r_{2}}\left(r_{2}-2 r_{1}\right)
$$

Observe that the optimal cash buffer for each firm depends positively on the fixed bound, $H$, of the distribution from which cash flow is drawn and the interest rate for external funds, $r_{2}$ and negatively on the opportunity cost of holding funds captured by $r_{1}$. Note that the firm is guaranteed to have positive cash holdings if $r_{2}>2 r_{1}$. Also note that when the managers have

\footnotetext{
${ }^{12}$ To simplify the argument, we do not consider the likelihood of liquidation and assume that the firm can borrow from an external source. Since in the empirical implementation we work with large, publicly traded firms, this should be generally reasonable.

${ }^{13}$ The second order condition, $\frac{\partial^{2} E C O S T}{\partial C_{i}^{2}}=\frac{r_{2}}{2 H}>0$, confirms that we have a minimum.
} 
full information on the bounds of the cash flow distribution, each firm holds an identical amount of cash. However, in real life, this is hardly the case. ${ }^{14}$

\subsubsection{The augmented cash buffer-stock model}

Let us now assume that each firm experiences a random shock to their cash flow of the size $\epsilon_{i, t}$. In this context, $\epsilon_{i, t}$ represents the level of uncertainty of net disbursements that is faced by each firm. We assume that $\epsilon_{i, t}$ is distributed normally with mean 0 and variance $\sigma_{\epsilon, t}^{2}$ across all firms, ${ }^{15}$ implying that the bounds of the cash flow distribution will now be random. Hence, the upper bound of the cash flow for each firm $i$ will be equal to $H_{i, t}=H+\epsilon_{i, t}$. Let us further assume that manager of each firm at time $t$ observes a signal $S_{i, t}=\epsilon_{i, t}+\nu_{t}$ where $\nu_{t}$ denotes noise, which is normally distributed as $\nu_{t} \sim$ $N\left(0, \sigma_{\nu, t}^{2}\right)$ and independent of $\epsilon_{i, t}$. The noise in the signal is assumed to reflect macroeconomic uncertainty, in the sense that a larger variance of $\nu_{t}$ makes the manager unable to accurately predict the bounds of the distribution, as would higher uncertainty in the economy. Contrarily, greater stability of macroeconomic conditions would allow one to make accurate predictions of the bounds of the distribution.

By employing the above framework, we assume that the manager takes all available information into consideration before making any decision to minimize the cost of holding a cash buffer-stock. Although the manager can still make suboptimal decisions (as the information content of the signal tends to change over time), the presence of the additional information contained in

\footnotetext{
${ }^{14}$ One can argue that in reality interest rates faced by each firm will differ across firms leading to differences across firms with respect to their cash buffer. In the next section we will provide another rationale for this heterogeneity without resorting to (generally unobservable) firm-specific costs of borrowing.

${ }^{15}$ This approach captures the idea that probability of observing small shocks is higher than that of larger ones.
} 
$S_{i, t}$ makes it possible to improve upon the naïve prediction of a zero value for $\epsilon_{i, t}$. After conditioning upon the signal $S_{i, t}$, the manager forms an optimal forecast of the range of net disbursements as $E_{t}\left(\epsilon_{i, t} \mid S_{i, t}\right)=\lambda_{t} S_{i, t}$, where $\lambda_{t}=$ $\operatorname{Cov}\left(\epsilon_{i, t} \mid S_{i, t}\right) / \operatorname{Var}\left(S_{i, t}\right)=\frac{\sigma_{\epsilon, t}^{2}}{\sigma_{\epsilon, t}^{2}+\sigma_{\nu, t}^{2}}$. Therefore, substituting for $E_{t}\left(H_{i, t} \mid S_{i, t}\right)=$ $H+\lambda_{t} S_{i, t}$, we can modify equation (5) as:

$$
E\left(C_{i, t} \mid S_{i, t}\right)=\left(H+\lambda_{t} S_{i, t}\right)\left(\frac{r_{2}-2 r_{1}}{r_{2}}\right)=k H+k \lambda_{t} S_{i, t},
$$

where $k=\left(\frac{r_{2}-2 r_{1}}{r_{2}}\right)>0$, so that optimal cash holdings $C_{i, t}$ are positive as long as $r_{2}>2 r_{1}$. The difference of this new optimal cash level and that given in equation (5) is in the second term: $k \lambda_{t} S_{i, t}$. As macroeconomic uncertainty increases, $\lambda_{t}$ will diminish and equation (6) will no longer differ from equation (5). However, if the economic environment is stable, then the manager will be better off using equation (6). Although equation (6) does not yield an estimable equation in levels as it contains the idiosyncratic signal $S_{i, t}$, we may still exploit it to compute the cross-sectional distribution of cash holdings for each period:

$$
\operatorname{Var}\left(C_{i, t} \mid S_{i, t}\right)=k^{2} \lambda_{t}^{2} \operatorname{Var}\left(S_{i, t}\right)=\frac{k^{2} \sigma_{\epsilon, t}^{4}}{\sigma_{\epsilon, t}^{2}+\sigma_{\nu, t}^{2}} .
$$

This equation relates the cross-sectional variance of firms' cash holdings to macroeconomic uncertainty. If the macroeconomic situation becomes less predictable or "noisier" (i.e., when $\sigma_{\nu, t}^{2}$ becomes large), the firms behave more conservatively, leading to a narrowing in the cross-sectional distribution:

$$
\frac{\partial \operatorname{Var}\left(C_{i, t} \mid S_{i, t}\right)}{\partial \sigma_{\nu, t}^{2}}=-\frac{k^{2} \sigma_{H, t}^{4}}{\left(\sigma_{H, t}^{2}+\sigma_{\nu, t}^{2}\right)^{2}}<0 .
$$

To provide support for our hypothesis as displayed in equation (8), we investigate the link between macroeconomic uncertainty and changes in the cross-sectional distribution of the cash-to-asset ratio for U.S. non-financial 
firms. We expect to find that the spread of the distribution of the cashto-asset ratio - that is, the heterogeneity exhibited by non-financial firms' behavior - will be negatively related to macroeconomic uncertainty. To test our hypothesis, we consider the following reduced form equation:

$$
\operatorname{Disp}_{t}\left(C_{i t} / T A_{i t}\right)=\beta_{0}+\beta_{1} \tau_{t}^{2}+\epsilon_{t}
$$

where $\operatorname{Disp}_{t}\left(C_{i t} / T A_{i t}\right)$ is a measure of the cross-sectional dispersion of firms' cash-to-asset ratio at time $t$, and $\tau_{t}^{2}$ stands for the measure of macroeconomic uncertainty at time $t$. We would expect to find a negative sign on $\beta_{1}$ if greater macroeconomic uncertainty was associated with a smaller dispersion of firms' cash-to-asset ratio.

In the model we derive heterogeneous behavior across non-financial firms from purely stochastic elements. However, in reality we might expect that different classes of firms respond differently to shocks. In the empirical analysis, we consider subgroups of firms with various defining characteristics (size, growth rate, product mix, financial constraints) to verify this expectation.

\subsection{Identifying macroeconomic uncertainty}

In order to test our hypothesis that there exists a negative relationship between the cross sectional variance of firms' cash-to-asset ratio and macroeconomic uncertainty, we must provide a proxy that captures the state of the macroeconomy. To provide such a proxy we compute the conditional variance of a monthly measure of real gross domestic product as a measure of overall macroeconomic activity. ${ }^{16}$ The conditional variance of real GDP is

\footnotetext{
${ }^{16}$ Real GDP is available at a quarterly frequency; we use the proportional Denton procedure to generate a monthly series, using the index of industrial production (which is available at a monthly frequency) as an interpolating variable.
} 
well suited for our purposes to measure the stability of the macroeconomy. ${ }^{17}$ Therefore, we rewrite equation (9) in the following form:

$$
\operatorname{Disp}_{t}\left(C_{i t} / T A_{i t}\right)=\beta_{0}+\beta_{1} \hat{h}_{t}+\epsilon_{t}
$$

where $\hat{h}_{t}$ denotes the measure of macroeconomic uncertainty, captured by the conditional variance of real GDP evaluated at time $t$. The advantage of this approach is that we can relate the behavior of cash holdings directly to a measurable variable for economic uncertainty.

Our proxy for macroeconomic uncertainty is derived from quarterly real GDP (International Financial Statistics series 99BRZF) and monthly industrial production (International Financial Statistics series 66IZF). We generated the monthly GDP series using the proportional Denton procedure dentonmq (Baum, 2001), and fit a generalized ARCH $(\operatorname{GARCH}(2,2))$ model to the deviations of the series from an exponential trend, where the mean equation is an AR(1) model. ${ }^{18}$ The conditional variance derived from this GARCH model, averaged to annual frequency, is then used as our measure of macroeconomic uncertainty $\left(\hat{h}_{t}\right) \cdot{ }^{19}$

\footnotetext{
${ }^{17}$ Results using the conditional variance of industrial production were strong and similar to those obtained from the conditional variance of real GDP. Since the latter measure captures overall economic activity, we present only those results.

${ }^{18}$ To save space, details of the estimated GARCH model are not presented here but are available upon request.

${ }^{19}$ Since $\hat{h}_{t}$ is a generated regressor, potentially measured with error, we employ a generalized method of moments (GMM) instrumental variables estimation technique. Tests of the orthogonality of the generated regressor to the error (the "difference in Hansen $J$ " or "C" statistic: see Baum et al. (2003, pp. 20-24)) reject their null hypothesis in almost every case. In contrast, the overidentifying restrictions are generally accepted following the GMM estimation.
} 


\section{Empirical findings}

\subsection{The data}

The COMPUSTAT Industrial Annual database of U.S. non-financial firms is used for testing our hypothesis. It covers on average 3,600 firms' annual characteristics from 1957 to 2000. The firms are classified by four-digit Standard Industrial Classification (SIC) code. We consider all firms outside of one-digit codes 6 (finance, insurance and real estate) and 9 (government enterprises), and two-digit code 49 (utilities). We utilize COMPUSTAT data items Cash (data1) and Total Assets (data6) to construct the Cash-toAsset ratio. ${ }^{20}$ In order to evaluate the severity of firms' financial constraints, we compute the dividend payout ratio as $\frac{\text { data21 }}{\text { data13-data15-data16 }}$, where data21, data13, data15 and data16 correspond to Dividends-Common, Operating Income before Depreciation, Interest Expense and Income Taxes-Total respectively.

We apply a number of sample selection criteria on our original sample of 201,143 firm-years. First, we marked non-positive values of cash and total assets as missing. Second, we considered that values of the cash-to-asset ratio beyond three standard deviations from the mean were implausible; this only affected 5,352 firm-years, placing an effective upper bound on the cashto-asset ratio of 0.72 . Third, our model should be applied to firms who have not undergone substantial changes in their composition during the sample period (e.g., participation in a merger, acquisition or substantial divestment should be disqualifying). Since we do not directly observe these phenomena, we calculate the growth rate of each firm's real total assets, and trim the annual distribution of this growth rate by the 10th and 90th percentiles to

\footnotetext{
${ }^{20}$ Empirical results obtained using an alternative measure, the Cash-to-Non-CashAsset ratio, are qualitatively similar and available upon request.
} 
remove firms exhibiting substantial changes in their scale. Fourth, we wish to exclude firms in clear financial distress or those facing substantial liquidity constraints. We consider two years of negative cash flows as an indicator of these conditions. Where these appear, we remove them as well as the prior and subsequent cash flows from the sample. These screens collectively reduced the sample to 153,690 firm-years. ${ }^{21}$

Descriptive statistics for the annual means of cash-to-asset ratios are presented in Table 1. From the means of the sample we see that firms hold almost 12 percent of their total assets in cash. We also split our dataset on large and small firms. A firm is considered to be LARGE if its total assets are above the 90th percentile by year, and SMALL if its total assets are below the 25th percentile for that year. ${ }^{22}$ There are significant differences in behavior between large and small firms, with large firms having cash-to-assets ratio 5.6 percent lower than that of small firms. This can be explained by the fact that large firms have easier access to external financing, and they may face economies of scale in cash management.

On the basis of firms' SIC codes, we subdivided the data of the manufacturing sector firms (two-digit SIC 20-39) into producers of durable goods and producers of non-durable goods. A firm is considered DURABLE if its primary SIC code is 24,25 , or $32-39 .{ }^{23}$ SIC codes for NON-DURABLE industries are 20-23 and 26-31. ${ }^{24}$ We find that manufacturers of durable and

\footnotetext{
${ }^{21}$ Empirical results drawn from the full sample yielded qualitatively similar findings; we prefer to use the screened data to reduce the potential impact of outliers upon the parameter estimates.

${ }^{22}$ These asymmetric bounds have been chosen, given the highly skewed distribution of firms' assets, in order to roughly equalize the number of firm-years in each category.

${ }^{23}$ These industries include lumber and wood products, furniture, stone, clay, and glass products, primary and fabricated metal products, industrial machinery, electronic equipment, transportation equipment, instruments, and miscellaneous manufacturing industries.

${ }^{24}$ These industries include food, tobacco, textiles, apparel, paper products, printing
} 
non-durable goods have average cash-to-asset ratios differing by 0.8 percent.

We divided firms into high-growth and low-growth categories, defining those categories as above the 75 th percentile and below the 25 th percentile of the annual distribution of the growth in real total assets, respectively. We find that high-growth firms hold, on average, 0.8 percent more cash relative to total assets than do low-growth firms.

We also analysed the distinction between firms that might be considered financially constrained and those that might be considered financially unconstrained. Following the literature, we used the dividend payout ratio as a measure of financial stringency, defining those firms which lay below the 25th percentile of the annual distribution - or those firms paying zero dividends - to be financially constrained. ${ }^{25}$ We defined those firms above the 75th percentile of the annual distribution of the dividend payout ratio to be financially unconstrained. We find that the average cash-to-asset ratios of financially constrained and unconstrained firms differ by 1.3 percent, with the latter firms holding more cash.

\subsection{The link between cash holdings and uncertainty}

The results of estimating Equation (10) are given in Tables 2-10 for all firms and four category splits (large/small, durable/non-durable goods manufacturers, low and high growth firms, and financially constrained/unconstrained firms, respectively). In those tables, we present GMM (instrumental variablesgeneralized method of moments) estimation results, ${ }^{26}$ where the macroeco-

and publishing, chemicals, petroleum and coal products, rubber and plastics, and leather products makers.

${ }^{25}$ There is a notable trend toward lower dividend payout ratios during the period of analysis, so that even the median firm had a zero payout ratio after 1985 .

${ }^{26}$ The rationale for this approach is discussed above in section 2.2 . 
nomic uncertainty proxy Lwcvgdp is a weighted average of lagged effects. ${ }^{27,28}$ Column (2) of each table presents results of regressions adding two control variables: the rate of CPI inflation and the detrended index of leading indicators (computed from DRI-McGraw Hill Basic Economics series DLEAD), to check for stability of our results in the presence of these factors, reflecting level effects from the macroeconomic environment. We consider the potential impact of interest rates on cash-holding behavior in columns (3) and (4), which include the three-month Treasury bill rate $(T B 3 m o)$ and the threemonth LIBOR rate, LIBOR3mo, as a proxy for the private cost of funds. Column (5) combines the variables added in column (2) with LIBOR3mo, which is the more successful interest rate variable. The last two rows of each table report $\hat{\eta}$, the estimated elasticities of the dispersion of the cash/asset ratio with respect to Lwcvgdp, and their estimated standard errors, labelled "s.e.".

The results indicate that there is a negative and significant relationship between the cross-sectional distribution of non-financial firms' cash-to-asset ratios and a proxy for macroeconomic uncertainty. For all firms, as presented in Table 2, the elasticities with respect to the macroeconomic uncertainty measures are similar across the specifications, and each significantly differs from zero. These results support the model, with the proxy for macroeconomic uncertainty having sizable and stable effects.

There are interesting differences in the results for large and small firms, as presented in Tables 3 and 4, respectively. The findings for large firms have

\footnotetext{
${ }^{27}$ We imposed an arithmetic lag on the values of the proxy variable for periods $t-1, t-2$, $t-3$ and $t-4$, with weights $0.4,0.3,0.2$ and 0.1 respectively, to capture the combined effect of contemporaneous and lagged uncertainty on cash holding behavior. Analysis based on contemporaneous and once-lagged uncertainty yielded similar results..

${ }^{28}$ Use of similar measures based on the conditional variance of industrial production as a regressor yielded qualitatively similar results. These are available from the authors upon request.
} 
similar explanatory power to those for all firms, with estimated elasticities even larger than their counterparts in Table 2. In contrast, the elasticities for small firms exhibit about half as much sensitivity to macroeconomic uncertainty, with lower levels of significance. This difference may be due to the fact that small firms hold significantly larger amounts of cash than their larger counterparts, who are likely to enjoy better access to credit markets. Hence, our regression results imply that small firms find more room to maneuver during turbulent periods in comparison to larger firms.

A quite striking contrast may be observed between durable-goods makers (Table 5) and non-durable goods manufacturers (Table 6). The former firms have a marked sensitivity to macroeconomic uncertainty, with estimated elasticities considerably larger than those for all firms or even for large firms. In contrast, non-durable goods makers exhibit much lower sensitivities to macroeconomic uncertainty. ${ }^{29}$ This distinction can be better understood by noting that non-durable goods producers are expected to have lower levels of finished goods inventories compared to durable goods producers. Since durable goods makers' products generally involve greater time lags in production and larger inventories of work-in-progress, they will behave more conservatively in their cash holdings policy to overcome the potential difficulties involved in times of higher uncertainty than will the non-durable goods producers.

Low-growth firms (reported in Table 7) are likely to be more mature firms, perhaps those in declining industries. They exhibit significant effects, with generally smaller estimated elasticities than those for all firms. In contrast, the impact of macroeconomic uncertainty on high-growth firms (as reported

\footnotetext{
${ }^{29}$ Joint estimation of the two equations as a SUR system allows for a test of equality of the column (5) estimates for Lwcvgdp. This test rejects at any conventional significance level, indicating that durable firms' sensitivity is significantly greater.
} 
in Table 8) is about twice as large. These firms - likely to be younger firms with substantial uncertainty about their near-term prospects-are considerably more sensitive to macroeconomic factors. Furthermore, one would expect that their access to external finance may be limited, requiring them to behave more cautiously, particularly in times of higher macroeconomic uncertainty.

The results for financially constrained versus unconstrained firms are quite striking (see tables 9 and 10, respectively), with the model having much lower explanatory power for the latter group of firms. For the financially constrained firms, the effects of macroeconomic uncertainty are quite substantial, with sizable estimated elasticities comparable to the effects noted for high-growth firms. This result is also quite intuitive. As uncertainty in the macroeconomic environment increases, financially constrained firms would want to accumulate larger cash buffers to weather the storm while the unconstrained firms can be expected to have more latitude to behave idiosyncratically.

In summary, we find support for the model's predictions for the entire set of firms considered, and find, as well, that the model is more strongly supported for some categories of firms than for others. Not surprisingly, the effects of macroeconomic uncertainty differ with respect to firm-specific characteristics. Large firms with substantial exposure to macro demand conditions exhibit greater sensitivity. Since durable goods makers' products generally involve greater time lags in production and larger inventories of workin-progress, they are also more sensitive to macroeconomic uncertainty than are nondurable-goods producers. Firms experiencing rapid growth-often a synonym for young firms with substantial uncertainty over their eventual prospects - and firms that might be considered financially constrained are 
found to be quite sensitive to macroeconomic uncertainty. Finally, firms that are paying sizable dividends, and might be considered free of financial constraints, do not exhibit sensitivity to these macro effects.

\section{Conclusions}

In this paper we focus on the link between the dispersion of firms' cashto-assets ratios and macroeconomic uncertainty using a panel of U.S. nonfinancial firms. Based on an augmented cash buffer-stock model, we demonstrate that firms become more homogeneous in their cash-holding behavior in response to an increase in macroeconomic uncertainty. Conversely, when the macroeconomic environment is more stable, firms have more latitude to behave idiosyncratically, leading to a broadening of the cross-sectional dispersion of firms' cash-to-asset ratios. To test the predictions of our model, we estimate a simple reduced-form equation using an annual data set describing individual firms' behavior and a proxy for macroeconomic uncertainty derived from monthly estimates of real GDP. On the basis of our empirical findings, we suggest that large firms, durable-goods makers, high-growth firms and financially constrained firms make larger adjustments in their cash holdings in response to macroeconomic volatility than will smaller or more slowly growing firms, those producing non-durable goods, or those who do not face financial constraints. These results are shown to be robust to the inclusion of the levels of macroeconomic factors such as the index of leading indicators, the rate of inflation, and short-term Treasury and LIBOR interest rates. 
Appendix: Construction of cash holdings and uncertainty measures

The following variables are used in the empirical study.

From Standard and Poor's COMPUSTAT database:

DNUM: Industry Classification Code

DATA1: Cash Holdings

DATA6: Total Assets

DATA13: Operating Income before Depreciation

DATA15: Interest Expense

DATA16: Income Taxes-Total

DATA21: Dividends-Common

From International Financial Statistics:

66IZF: Industrial Production monthly

64XZF: Consumer Price Inflation

99BRZF: GDP at 1996 prices

From the DRI-McGraw Hill Basic Economics database:

DLEAD: index of leading indicators 


\section{References}

[1] Almeida, Heitor, Murillo Campello and Michael Weisbach, 2004. The Cash Flow Sensitivity of Cash. Journal of Finance, in press.

[2] Baum, Christopher F., 2001. "DENTON: Stata module to interpolate a quarterly flow series from annual totals via proportional Denton method." http://ideas.repec.org/c/boc/bocode/s422501.html.

[3] Baum, Christopher F., Mustafa Caglayan and Neslihan Ozkan, 2002. The impact of macroeconomic uncertainty on bank lending behavior. Boston College WP No. 521; University of Liverpool WP 2002-02.

[4] Baum, Christopher F., Mark E. Schaffer, and Steven Stillman, 2003. Instrumental variables and GMM: Estimation and testing. Stata Journal, $3,1-31$.

[5] Beaudry, Paul, Mustafa Caglayan and Fabio Schiantarelli, 2001. Monetary instability, the predictability of prices, and the allocation of investment: An empirical investigation using U.K. panel data. American Economic Review, 91, 648-62.

[6] Dittmar, Amy, Jan Mahrt-Smith and Henri Servaes, 2003. International Corporate Governance and Corporate Cash Holdings. Journal of Financial and Quantitative Analysis, 38:1, 111-33.

[7] Faulkender, Michael, 2002. Cash holdings among small businesses. Northwestern University, unpublished working paper.

[8] Frenkel, Jacob A. and Boyan Jovanovich 1980. On transactions and precautionary demand for Money. Quarterly Journal of Economics, 95:1, $25-43$.

[9] Harford, J., 1999. Corporate cash reserves and acquisitions. Journal of Finance, 54, 1969-1997.

[10] Kester, W. Carl, 1986. Capital and ownership structure: A comparison of U.S. and Japanese manufacturing corporations. Financial Management, 15, 5-16.

[11] Keynes, John Maynard, 1936. The general theory of employment, interest and money. London: Harcourt Brace.

[12] Kim, Chang-Soo, David C. Mauer and Ann E. Sherman, 1998. The determinants of corporate liquidity: Theory and evidence. Journal of Financial and Quantitative Analysis, 33, 335-359. 
[13] Opler, Tim, Lee Pinkowitz, Rene Stulz and Rohan Williamson, 1999. The determinants and implications of cash holdings. Journal of Financial Economics, 52, 3-46.

[14] Ozkan, Aydin and Neslihan Ozkan, 2003. Corporate cash holdings: An empirical investigation of UK companies. Journal of Banking and Finance, in press.

[15] Schnure, Calvin. Who holds cash? and why?, (1998) Finance and Economics Discussion Series No. 1998-13, Board of Governors of the Federal Reserve System.

[16] Whalen, Edward, 1966. A Rationalization of the Precautionary Demand for Cash. Quarterly Journal of Economics, 80, 314-324. 
Table 1: Mean of Annual Cash/Asset ratios: Descriptive statistics

\begin{tabular}{llllllr}
\hline & $\mu$ & $\sigma$ & $p 25$ & $p 50$ & $p 75$ & $N$ \\
\hline All firms & 0.119 & 0.029 & 0.099 & 0.114 & 0.128 & 153,690 \\
Small firms & 0.143 & 0.020 & 0.126 & 0.142 & 0.151 & 24,907 \\
Large firms & 0.087 & 0.032 & 0.069 & 0.074 & 0.097 & 19,270 \\
Durable goods firms & 0.121 & 0.033 & 0.092 & 0.121 & 0.137 & 55,351 \\
Non-durable goods firms & 0.113 & 0.028 & 0.090 & 0.104 & 0.141 & 33,576 \\
Low-growth firms & 0.112 & 0.021 & 0.092 & 0.110 & 0.132 & 29,636 \\
High-growth firms & 0.120 & 0.024 & 0.099 & 0.122 & 0.141 & 29,591 \\
Financially constrained firms & 0.113 & 0.022 & 0.093 & 0.112 & 0.123 & 70,932 \\
Unconstrained firms & 0.126 & 0.049 & 0.092 & 0.101 & 0.165 & 35,719 \\
\hline
\end{tabular}

Note: $p 25, p 50$ and $p 75$ represent the quartiles of the distribution, while $\mu$ and $\sigma$ represent its mean and standard deviation. $N$ refers to the number of firm-years of data in each category which have been collapsed into 48 annual observations (42 years for the growth categories). 
Table 2. Dispersion of Cash/Asset ratio for all firms

\begin{tabular}{|c|c|c|c|c|c|}
\hline & $\begin{array}{c}\text { (1) } \\
\text { RAT1_Sig }\end{array}$ & $\begin{array}{c}(2) \\
\text { RAT1_Sig }\end{array}$ & $\begin{array}{c}(3) \\
\text { RAT1_Sig }\end{array}$ & $\begin{array}{c}(4) \\
\text { RAT1_Sig }\end{array}$ & $\begin{array}{c}(5) \\
\text { RAT1_Sig }\end{array}$ \\
\hline Lwcvgdp & $\begin{array}{c}-168.659 \\
{[24.598]^{* * *}}\end{array}$ & $\begin{array}{c}-134.880 \\
{[24.167]^{* * *}}\end{array}$ & $\begin{array}{c}-184.806 \\
{[29.166]^{* * *}}\end{array}$ & $\begin{array}{c}-185.172 \\
{[32.380]^{* * *}}\end{array}$ & $\begin{array}{c}-149.364 \\
{[23.272]^{* * *}}\end{array}$ \\
\hline Inflation & & $\begin{array}{c}-0.003 \\
{[0.001]^{* * *}}\end{array}$ & & & $\begin{array}{c}-0.006 \\
{[0.001]^{* * *}}\end{array}$ \\
\hline LeadIndic & & $\begin{array}{c}-0.003 \\
{[0.001]^{* * *}}\end{array}$ & & & $\begin{array}{c}-0.002 \\
{[0.001]^{* * *}}\end{array}$ \\
\hline TB3mo & & & $\begin{array}{l}0.163 \\
{[0.132]}\end{array}$ & & \\
\hline LIBOR3mo & & & & $\begin{array}{l}0.091 \\
{[0.108]}\end{array}$ & $\begin{array}{c}0.431 \\
{[0.118]^{* * *}}\end{array}$ \\
\hline Constant & $\begin{array}{c}0.210 \\
{[0.011]^{* * *}}\end{array}$ & $\begin{array}{c}0.208 \\
{[0.010]^{* * *}}\end{array}$ & $\begin{array}{c}0.207 \\
{[0.010]^{* * *}}\end{array}$ & $\begin{array}{c}0.212 \\
{[0.011]^{* * *}}\end{array}$ & $\begin{array}{c}0.197 \\
{[0.009]^{* * *}}\end{array}$ \\
\hline $\begin{array}{l}\text { Observations } \\
\hat{\eta} \\
\text { s.e. }\end{array}$ & $\begin{array}{c}38 \\
-0.77 \\
0.13\end{array}$ & $\begin{array}{c}38 \\
-0.61 \\
0.12\end{array}$ & $\begin{array}{c}38 \\
-0.85 \\
0.16\end{array}$ & $\begin{array}{c}38 \\
-0.85 \\
0.17\end{array}$ & $\begin{array}{c}38 \\
-0.68 \\
0.12\end{array}$ \\
\hline
\end{tabular}


Table 3. Dispersion of Cash/Asset ratio for large firms

\begin{tabular}{|c|c|c|c|c|c|}
\hline & $\begin{array}{c}(1) \\
\text { RAT1_Sig }\end{array}$ & $\begin{array}{c}(2) \\
\text { RAT1_Sig }\end{array}$ & $\begin{array}{c}(3) \\
\text { RAT1_Sig }\end{array}$ & $\begin{array}{c}(4) \\
\text { RAT1_Sig }\end{array}$ & $\begin{array}{c}(5) \\
\text { RAT1_Sig }\end{array}$ \\
\hline Lwcvgdp & $\begin{array}{c}-133.863 \\
{[16.317]^{* * *}}\end{array}$ & $\begin{array}{c}-101.122 \\
{[15.638]^{* * *}}\end{array}$ & $\begin{array}{c}-123.634 \\
{[19.888]^{* * *}}\end{array}$ & $\begin{array}{c}-120.773 \\
{[21.775]^{* * *}}\end{array}$ & $\begin{array}{c}-101.272 \\
{[14.039]^{* * *}}\end{array}$ \\
\hline Inflation & & $\begin{array}{c}-0.002 \\
{[0.001]^{* * *}}\end{array}$ & & & $\begin{array}{c}-0.003 \\
{[0.001]^{* * *}}\end{array}$ \\
\hline LeadIndic & & $\begin{array}{c}-0.001 \\
{[0.000]^{* * *}}\end{array}$ & & & $\begin{array}{c}-0.001 \\
{[0.000]^{* *}}\end{array}$ \\
\hline TB3mo & & & $\begin{array}{l}-0.053 \\
{[0.086]}\end{array}$ & & \\
\hline LIBOR3mo & & & & $\begin{array}{l}-0.070 \\
{[0.064]}\end{array}$ & $\begin{array}{l}0.080 \\
{[0.073]}\end{array}$ \\
\hline Constant & $\begin{array}{c}0.145 \\
{[0.007]^{* * *}}\end{array}$ & $\begin{array}{c}0.140 \\
{[0.005]^{* * *}}\end{array}$ & $\begin{array}{c}0.144 \\
{[0.007]^{* * *}}\end{array}$ & $\begin{array}{c}0.144 \\
{[0.007]^{* * *}}\end{array}$ & $\begin{array}{c}0.137 \\
{[0.005]^{* * *}}\end{array}$ \\
\hline $\begin{array}{l}\text { Observations } \\
\hat{\eta} \\
\text { s.e. }\end{array}$ & $\begin{array}{c}38 \\
-1.00 \\
0.15\end{array}$ & $\begin{array}{c}38 \\
-0.73 \\
0.13\end{array}$ & $\begin{array}{c}38 \\
-0.91 \\
0.17\end{array}$ & $\begin{array}{c}38 \\
-0.89 \\
0.18\end{array}$ & $\begin{array}{c}38 \\
-0.74 \\
0.12\end{array}$ \\
\hline & & tandard & in bracl & & \\
\hline
\end{tabular}


Table 4. Dispersion of Cash/Asset ratio for small firms

\begin{tabular}{|c|c|c|c|c|c|}
\hline & $\begin{array}{c}(1) \\
\text { RAT1_Sig }\end{array}$ & $\begin{array}{c}(2) \\
\text { RAT1_Sig }\end{array}$ & $\begin{array}{c}(3) \\
\text { RAT1_Sig }\end{array}$ & $\begin{array}{c}(4) \\
\text { RAT1_Sig }\end{array}$ & $\begin{array}{c}(5) \\
\text { RAT1_Sig }\end{array}$ \\
\hline Lwcvgdp & $\begin{array}{c}-114.644 \\
{[22.407]^{* * *}}\end{array}$ & $\begin{array}{c}-89.415 \\
{[17.790]^{* * *}}\end{array}$ & $\begin{array}{c}-130.703 \\
{[24.224]^{* *}}\end{array}$ & $\begin{array}{c}-140.800 \\
{[28.542]^{* * *}}\end{array}$ & $\begin{array}{c}-92.495 \\
{[21.112]^{* * *}}\end{array}$ \\
\hline Inflation & & $\begin{array}{l}-0.001 \\
{[0.001]}\end{array}$ & & & $\begin{array}{c}-0.004 \\
{[0.001]^{* * *}}\end{array}$ \\
\hline LeadIndic & & $\begin{array}{c}-0.002 \\
{[0.001]^{* * *}}\end{array}$ & & & $\begin{array}{c}-0.002 \\
{[0.001]^{* * *}}\end{array}$ \\
\hline TB3mo & & & $\begin{array}{c}0.338 \\
{[0.100]^{* * *}}\end{array}$ & & \\
\hline LIBOR3mo & & & & $\begin{array}{c}0.252 \\
{[0.078]^{* * *}}\end{array}$ & $\begin{array}{c}0.398 \\
{[0.128]^{* * *}}\end{array}$ \\
\hline Constant & $\begin{array}{c}0.203 \\
{[0.012]^{* * *}}\end{array}$ & $\begin{array}{c}0.193 \\
{[0.006]^{* * *}}\end{array}$ & $\begin{array}{c}0.191 \\
{[0.010]^{* * *}}\end{array}$ & $\begin{array}{c}0.199 \\
{[0.011]^{* * *}}\end{array}$ & $\begin{array}{c}0.181 \\
{[0.009]^{* * *}}\end{array}$ \\
\hline $\begin{array}{l}\text { Observations } \\
\hat{\eta} \\
\text { s.e. }\end{array}$ & $\begin{array}{c}38 \\
-0.44 \\
0.09\end{array}$ & $\begin{array}{c}38 \\
-0.34 \\
0.07\end{array}$ & $\begin{array}{c}38 \\
-0.50 \\
0.10\end{array}$ & $\begin{array}{c}38 \\
-0.54 \\
0.12\end{array}$ & $\begin{array}{c}38 \\
-0.35 \\
0.08\end{array}$ \\
\hline
\end{tabular}


Table 5. Dispersion of Cash/Asset ratio for durable-goods firms

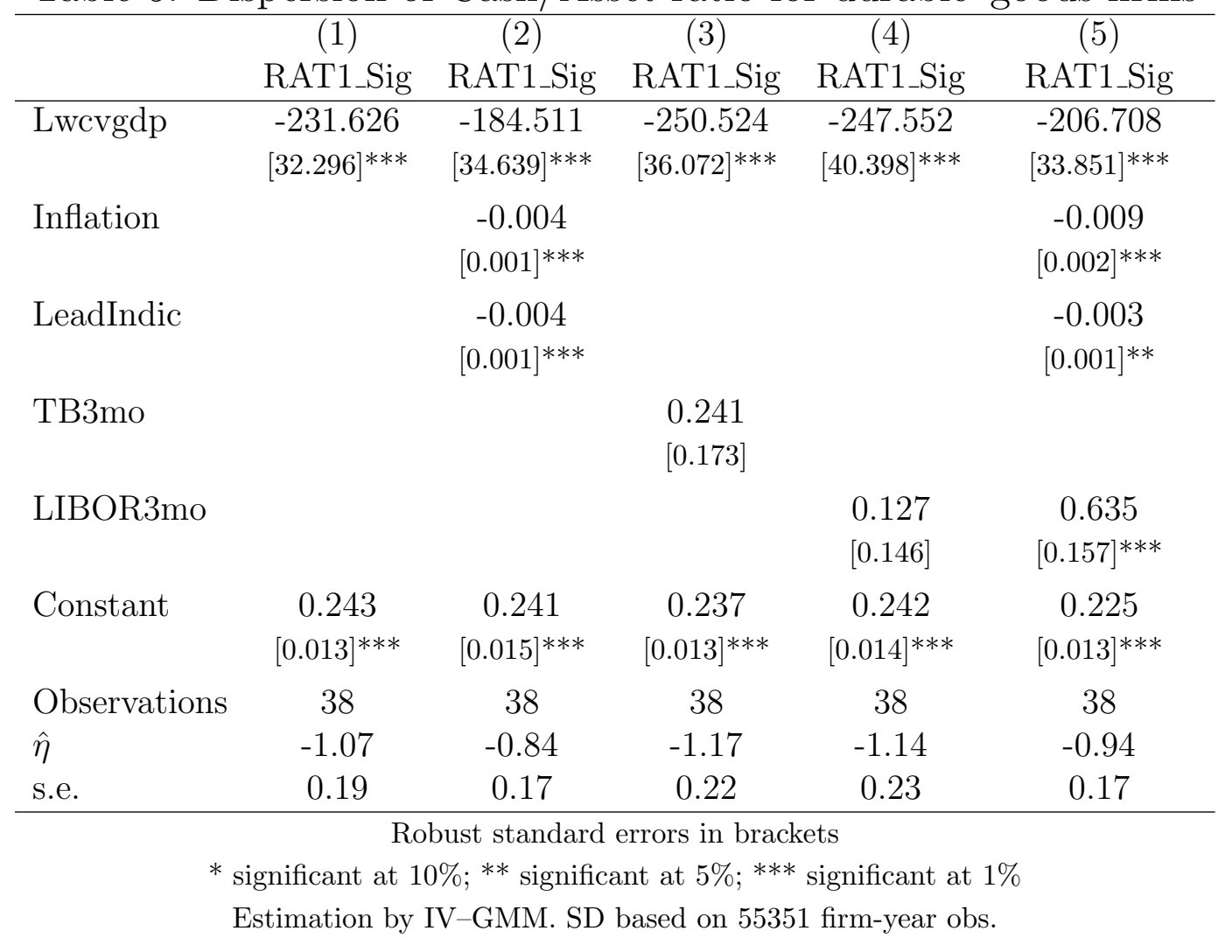


Table 6. Dispersion of Cash/Asset ratio for nondurable-goods firms

\begin{tabular}{|c|c|c|c|c|c|}
\hline & $\begin{array}{c}(1) \\
\text { RAT1_Sig }\end{array}$ & $\begin{array}{c}(2) \\
\text { RAT1_Sig }\end{array}$ & $\begin{array}{c}(3) \\
\text { RAT1_Sig }\end{array}$ & $\begin{array}{c}(4) \\
\text { RAT1_Sig }\end{array}$ & $\begin{array}{c}(5) \\
\text { RAT1_Sig }\end{array}$ \\
\hline Lwcvgdp & $\begin{array}{c}-64.479 \\
{[15.139]^{* * *}}\end{array}$ & $\begin{array}{c}-42.984 \\
{[8.752]^{* * *}}\end{array}$ & $\begin{array}{c}-67.774 \\
{[16.453]^{* * *}}\end{array}$ & $\begin{array}{c}-69.713 \\
{[18.384]^{* * *}}\end{array}$ & $\begin{array}{c}-40.292 \\
{[9.002]^{* * *}}\end{array}$ \\
\hline Inflation & & $\begin{array}{c}-0.002 \\
{[0.000]^{* * *}}\end{array}$ & & & $\begin{array}{c}-0.004 \\
{[0.001]^{* * *}}\end{array}$ \\
\hline LeadIndic & & $\begin{array}{c}-0.001 \\
{[0.000]^{* * *}}\end{array}$ & & & $\begin{array}{c}-0.001 \\
{[0.000]^{* * *}}\end{array}$ \\
\hline TB3mo & & & $\begin{array}{l}0.081 \\
{[0.093]}\end{array}$ & & \\
\hline LIBOR3mo & & & & $\begin{array}{l}0.037 \\
{[0.074]}\end{array}$ & $\begin{array}{c}0.264 \\
{[0.062]^{* * *}}\end{array}$ \\
\hline Constant & $\begin{array}{c}0.139 \\
{[0.008]^{* * *}}\end{array}$ & $\begin{array}{c}0.137 \\
{[0.004]^{* * *}}\end{array}$ & $\begin{array}{c}0.135 \\
{[0.007]^{* * *}}\end{array}$ & $\begin{array}{c}0.139 \\
{[0.007]^{* * *}}\end{array}$ & $\begin{array}{c}0.126 \\
{[0.005]^{* * *}}\end{array}$ \\
\hline $\begin{array}{l}\text { Observations } \\
\hat{\eta} \\
\text { s.e. }\end{array}$ & $\begin{array}{c}38 \\
-0.34 \\
0.08\end{array}$ & $\begin{array}{c}38 \\
-0.22 \\
0.05\end{array}$ & $\begin{array}{c}38 \\
-0.35 \\
0.09\end{array}$ & $\begin{array}{c}38 \\
-0.36 \\
0.10\end{array}$ & $\begin{array}{c}38 \\
-0.21 \\
0.05\end{array}$ \\
\hline
\end{tabular}


Table 7. Dispersion of Cash/Asset ratio for low-growth firms

\begin{tabular}{|c|c|c|c|c|c|}
\hline & $\begin{array}{c}(1) \\
\text { RAT1_Sig }\end{array}$ & $\begin{array}{c}(2) \\
\text { RAT1_Sig }\end{array}$ & $\begin{array}{c}(3) \\
\text { RAT1_Sig }\end{array}$ & $\begin{array}{c}(4) \\
\text { RAT1_Sig }\end{array}$ & $\begin{array}{c}(5) \\
\text { RAT1_Sig }\end{array}$ \\
\hline Lwcvgdp & $\begin{array}{c}-116.977 \\
{[19.026]^{* * *}}\end{array}$ & $\begin{array}{c}-72.765 \\
{[16.704]^{* * *}}\end{array}$ & $\begin{array}{c}-114.998 \\
{[22.547]^{* * *}}\end{array}$ & $\begin{array}{c}-116.647 \\
{[24.924]^{* * *}}\end{array}$ & $\begin{array}{c}-84.195 \\
{[17.188]^{* * *}}\end{array}$ \\
\hline Inflation & & $\begin{array}{c}-0.003 \\
{[0.001]^{* * *}}\end{array}$ & & & $\begin{array}{c}-0.005 \\
{[0.001]^{* * *}}\end{array}$ \\
\hline LeadIndic & & $\begin{array}{c}-0.001 \\
{[0.001]^{* *}}\end{array}$ & & & $\begin{array}{l}-0.001 \\
{[0.001]}\end{array}$ \\
\hline TB3mo & & & $\begin{array}{l}0.020 \\
{[0.110]}\end{array}$ & & \\
\hline LIBOR3mo & & & & $\begin{array}{l}-0.002 \\
{[0.086]}\end{array}$ & $\begin{array}{c}0.283 \\
{[0.087]^{* * *}}\end{array}$ \\
\hline Constant & $\begin{array}{c}0.164 \\
{[0.010]^{* * *}}\end{array}$ & $\begin{array}{c}0.154 \\
{[0.006]^{* * *}}\end{array}$ & $\begin{array}{c}0.161 \\
{[0.008]^{* * *}}\end{array}$ & $\begin{array}{c}0.164 \\
{[0.009]^{* * *}}\end{array}$ & $\begin{array}{c}0.148 \\
{[0.007]^{* * *}}\end{array}$ \\
\hline $\begin{array}{l}\text { Observations } \\
\hat{\eta} \\
\text { s.e. }\end{array}$ & $\begin{array}{c}38 \\
-0.63 \\
0.11\end{array}$ & $\begin{array}{c}38 \\
-0.39 \\
0.09\end{array}$ & $\begin{array}{c}38 \\
-0.62 \\
0.13\end{array}$ & $\begin{array}{c}38 \\
-0.63 \\
0.14\end{array}$ & $\begin{array}{c}38 \\
-0.45 \\
0.10\end{array}$ \\
\hline
\end{tabular}


Table 8. Dispersion of Cash/Asset ratio for high-growth firms

\begin{tabular}{|c|c|c|c|c|c|}
\hline & $\begin{array}{c}(1) \\
\text { RAT1_Sig }\end{array}$ & $\begin{array}{c}(2) \\
\text { RAT1_Sig }\end{array}$ & $\begin{array}{c}(3) \\
\text { RAT1_Sig }\end{array}$ & $\begin{array}{c}(4) \\
\text { RAT1_Sig }\end{array}$ & $\begin{array}{c}(5) \\
\text { RAT1_Sig }\end{array}$ \\
\hline Lwcvgdp & $\begin{array}{c}-267.098 \\
{[38.274]^{* * *}}\end{array}$ & $\begin{array}{c}-190.969 \\
{[43.219]^{* * *}}\end{array}$ & $\begin{array}{c}-285.365 \\
{[44.121]^{* * *}}\end{array}$ & $\begin{array}{c}-296.038 \\
{[47.997]^{* * *}}\end{array}$ & $\begin{array}{c}-209.334 \\
{[45.002]^{* * *}}\end{array}$ \\
\hline Inflation & & $\begin{array}{c}-0.004 \\
{[0.001]^{* * *}}\end{array}$ & & & $\begin{array}{c}-0.008 \\
{[0.002]^{* * *}}\end{array}$ \\
\hline LeadIndic & & $\begin{array}{c}-0.003 \\
{[0.001]^{* * *}}\end{array}$ & & & $\begin{array}{c}-0.003 \\
{[0.001]^{* *}}\end{array}$ \\
\hline TB3mo & & & $\begin{array}{l}0.301 \\
{[0.192]}\end{array}$ & & \\
\hline LIBOR3mo & & & & $\begin{array}{l}0.182 \\
{[0.153]}\end{array}$ & $\begin{array}{c}0.517 \\
{[0.200]^{* * *}}\end{array}$ \\
\hline Constant & $\begin{array}{c}0.269 \\
{[0.018]^{* * *}}\end{array}$ & $\begin{array}{c}0.247 \\
{[0.018]^{* * *}}\end{array}$ & $\begin{array}{c}0.257 \\
{[0.016]^{* * *}}\end{array}$ & $\begin{array}{c}0.269 \\
{[0.017]^{* * *}}\end{array}$ & $\begin{array}{c}0.235 \\
{[0.016]^{* * *}}\end{array}$ \\
\hline $\begin{array}{l}\text { Observations } \\
\hat{\eta} \\
\text { s.e. }\end{array}$ & $\begin{array}{c}38 \\
-1.16 \\
0.20\end{array}$ & $\begin{array}{c}38 \\
-0.83 \\
0.20\end{array}$ & $\begin{array}{c}38 \\
-1.28 \\
0.24\end{array}$ & $\begin{array}{c}38 \\
-1.31 \\
0.26\end{array}$ & $\begin{array}{c}38 \\
-0.92 \\
0.21\end{array}$ \\
\hline
\end{tabular}


Table 9. Dispersion of Cash/Asset ratio for financially constrained firms

\begin{tabular}{|c|c|c|c|c|c|}
\hline & $\begin{array}{c}(1) \\
\text { RAT1_Sig }\end{array}$ & $\begin{array}{c}(2) \\
\text { RAT1_Sig }\end{array}$ & $\begin{array}{c}(3) \\
\text { RAT1_Sig }\end{array}$ & $\begin{array}{c}(4) \\
\text { RAT1_Sig }\end{array}$ & $\begin{array}{c}(5) \\
\text { RAT1_Sig }\end{array}$ \\
\hline Lwcvgdp & $\begin{array}{c}-194.170 \\
{[32.023]^{* * *}}\end{array}$ & $\begin{array}{c}-160.575 \\
{[24.451]^{* * *}}\end{array}$ & $\begin{array}{c}-219.221 \\
{[36.154]^{* * *}}\end{array}$ & $\begin{array}{c}-229.657 \\
{[41.144]^{* * *}}\end{array}$ & $\begin{array}{c}-155.202 \\
{[22.242]^{* * *}}\end{array}$ \\
\hline Inflation & & $\begin{array}{c}-0.002 \\
{[0.001]^{* *}}\end{array}$ & & & $\begin{array}{c}-0.007 \\
{[0.001]^{* * *}}\end{array}$ \\
\hline LeadIndic & & $\begin{array}{c}-0.003 \\
{[0.001]^{* * *}}\end{array}$ & & & $\begin{array}{c}-0.003 \\
{[0.001]^{* * *}}\end{array}$ \\
\hline TB3mo & & & $\begin{array}{c}0.390 \\
{[0.146]^{* * *}}\end{array}$ & & \\
\hline LIBOR3mo & & & & $\begin{array}{c}0.281 \\
{[0.119]^{* *}}\end{array}$ & $\begin{array}{c}0.575 \\
{[0.136]^{* * *}}\end{array}$ \\
\hline Constant & $\begin{array}{c}0.227 \\
{[0.015]^{* * *}}\end{array}$ & $\begin{array}{c}0.221 \\
{[0.009]^{* * *}}\end{array}$ & $\begin{array}{c}0.215 \\
{[0.014]^{* * *}}\end{array}$ & $\begin{array}{c}0.226 \\
{[0.015]^{* * *}}\end{array}$ & $\begin{array}{c}0.196 \\
{[0.009]^{* * *}}\end{array}$ \\
\hline $\begin{array}{l}\text { Observations } \\
\hat{\eta} \\
\text { s.e. }\end{array}$ & $\begin{array}{c}38 \\
-0.87 \\
0.16\end{array}$ & $\begin{array}{c}38 \\
-0.71 \\
0.12\end{array}$ & $\begin{array}{c}38 \\
-0.98 \\
0.19\end{array}$ & $\begin{array}{c}38 \\
-1.02 \\
0.21\end{array}$ & $\begin{array}{c}38 \\
-0.68 \\
0.11\end{array}$ \\
\hline
\end{tabular}


Table 10. Dispersion of Cash/Asset ratio for financially unconstrained firms

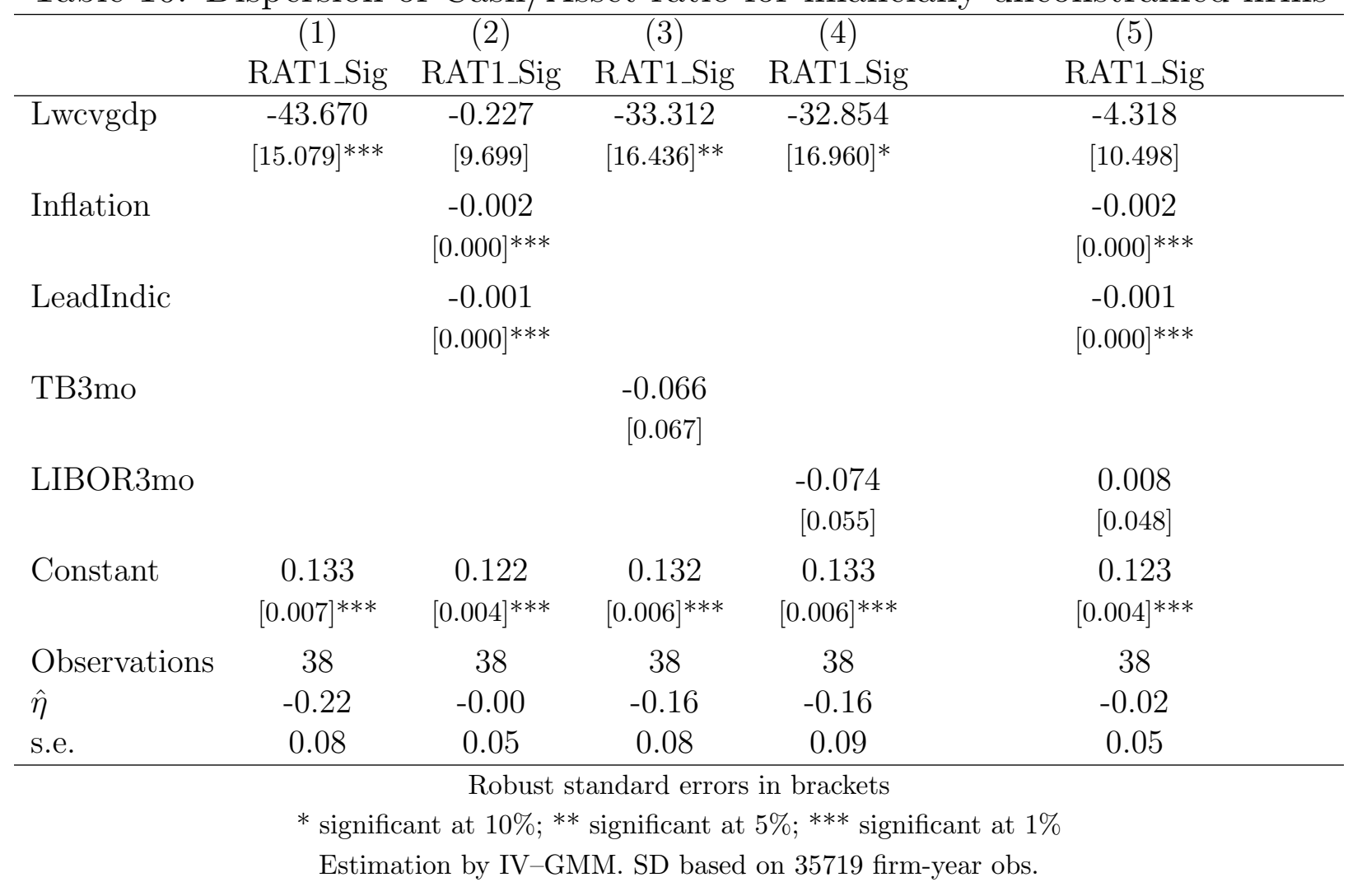

